\title{
Meat quality of Pantaneiro lambs at different body weights
}

\section{Qualidade da carne de cordeiros Pantaneiros de diferentes pesos corporais}

\author{
Adriana Sathie Ozaki Hirata ${ }^{1 *}$; Alexandre Rodrigo Mendes Fernandes ${ }^{2}$; Ingrid \\ Harumi de Souza Fuzikawa ${ }^{3}$; Fernando Miranda de Vargas Junior²; Hélio de \\ Almeida Ricardo ${ }^{4}$; Claudia Andréa Lima Cardoso ${ }^{5}$; Luis Gustavo Castro Alves ${ }^{6}$; \\ Natássia Gabriela Targanski Zagonel ${ }^{1}$
}

\begin{abstract}
The aim of this study was to assess the meat quality of Pantaneiro lambs finished in confinement and slaughtered at different body weights $(15,20,25,30$, and $35 \mathrm{~kg})$. Forty-five non-castrated male Pantaneiro lambs were distributed in a completely randomized design, with five treatments and nine replicates. The animals were housed in individual pens and slaughtered when they reached the target weights. For instrumental and centesimal analyses, the Semimembranosus, Longissimus lumborum, Gluteobiceps, and Triceps brachii muscles were used, whereas for fatty acid profile analysis only the Longissimus lumborum muscle was used. The different body weights influenced the final $\mathrm{pH}$ of the meat, but this still remained within the recommended values; however, the meat of heavier lambs had increased water-holding capacity (WHC), redness $\left(\mathrm{a}^{*}\right)$, and fat content, making it the tenderest but least luminous and humid meat. Greater body weight led to a higher saturated fatty acid (SFA) content, reduction of monounsaturated fatty acid (MUFA) and polyunsaturated fatty acid (PUFA), higher hypercholesterolemic fatty acid content $(\mathrm{H})$, and higher atherogenicity (AI) and thrombogenicity indexes (TI). Therefore, it was concluded that the meat of lambs slaughtered at lower body weight presented better nutritional quality, making it more suitable for human consumption.
\end{abstract}

Key words: Fatty acids. Lipids. Sheep. Tenderness.

\section{Resumo}

Objetivou-se avaliar a qualidade da carne de cordeiros Pantaneiros terminados em confinamento e abatidos com diferentes pesos corporais $(15,20,2530$ e $35 \mathrm{~kg})$. Foram utilizados 45 cordeiros Pantaneiros, machos, não castrados, distribuídos em um delineamento inteiramente casualizado, com cinco tratamentos e nove repetições. Os animais foram alojados em baias individuais e abatidos quando

\footnotetext{
${ }^{1}$ Mestres em Zootecnia, Universidade Federal da Grande Dourados, Faculdade de Ciências Agrárias, UFGD, Dourados, MS, Brasil. E-mail: adrianahirata@ufgd.edu.br; natassia_tz@hotmail.com

2 Profs. Drs., UFGD, Dourados, MS, Brasil. E-mail: alexandrefernandes@ufgd.edu.br; fernandojunior@ufgd.edu.br

3 Discente, Curso de Doutorado em Zootecnia, Universidade de São Paulo, Faculdade de Zootecnia e Engenharia de Alimentos, USP, Pirassununga, SP, Brasil. E-mail: ingrid.fuzikawa@gmail.com

4 Prof., Dr., Universidade Estadual Paulista "Júlio de Mesquita Filho", Faculdade de Medicina Veterinária e Zootecnia, Departamento de Produção Animal, UNESP, Botucatu, SP, Brasil. E-mail: haricardo@hotmail.com

5 Prof $^{a}$ Dr $^{\mathrm{a}}$, Universidade Estadual de Mato Grosso do Sul, Centro de Estudos em Recursos Naturais, UEMS, Dourados, MS, Brasil.E-mail: claudia@uems.br

6 Dr. em Ciência Animal, Universidade Estadual de Londrina, Centro de Ciências Agrárias, UEL, Londrina, PR, Brasil. E-mail: gustavo353@hotmail.com

* Author for correspondence
} 
atingiram os pesos pré-determinados. Para as análises instrumentais e centesimais, foram utilizados os músculos Semimembranosus, Longissimus lumborum, Gluteobiceps e Triceps brachii, enquanto que apenas o Longissimus lumborum foi utilizado para análise de perfil de ácidos graxos. Os diferentes pesos corporais influenciaram no $\mathrm{pH}$ final da carne, mas este se manteve ainda dentro do valor recomendado; porém, a elevação do peso corporal dos cordeiros, aumentou a capacidade de retenção de água (CRA), o índice de vermelho $\left(\mathrm{a}^{*}\right)$ e os teores de lipídeos da carne, deixando-a mais macia, porém, menos luminosa e úmida. O maior peso corporal levou a um maior teor de ácidos graxos saturados (AGS), redução nos teores de ácidos graxos monoinsaturados (AGMI) e poli-insaturados (AGPI), aumento da hipercolesterolemia (H) e dos índices de aterogenicidade (IA) e trombogenicidade (IT). Portanto, concluiu-se que a carne de cordeiros abatidos com menor peso corporal apresentou melhor qualidade nutricional, tornando-a mais adequada ao consumo humano.

Palavras-chave: Ácidos graxos. Lipídeos. Maciez. Ovinos.

\section{Introduction}

Lamb husbandry has become a promising activity for the Brazilian agribusiness, with a growing demand for its products, particularly meat. The expanding demand for these products provides great motivation for the productive chain to invest in better herd genetic quality, improve the final product, and offer it all year round. In this context, the use of local or naturalized animals is important due to their greater ability to adapt to local adverse conditions compared to introduced animals (OLIVEIRA et al., 2014).

In the state of Mato Grosso do Sul, Brazil, a genetic group of sheep temporarily called Nativo Sul-Matogrossense, or Pantaneiro, is particularly well adapted to the climatic conditions of the region (VARGAS JUNIOR et al., 2011). There is growing interest in Pantaneiro sheep from research institutions and universities, as well as from rural producers, as an alternative to sheep husbandry systems and generation of additional income in the Pantanal region. The rustic characteristics of these animals make them an attractive option for breeding and use, as the maternal breed for the region. However, more information is needed regarding the meat quality provided by this genetic group. Therefore, the aim of this study was to assess the meat quality of Pantaneiro lambs finished in confinement and slaughtered at different body weights.

\section{Material and Methods}

The experiment was carried out in the municipality of Dourados, MS, Brazil, located at $22^{\circ} 13^{\prime} 18^{\prime \prime} \mathrm{S}$ latitude, $54^{\circ} 48^{\prime} 23^{\prime \prime} \mathrm{W}$ longitude and at an altitude of $448 \mathrm{~m}$. The entire trial was conducted in accordance with ethical standards and approved by the Ethics Committee on Animal Use of the Federal University of Grande Dourados (protocol no. 018/2013).

Forty-five weaned non-castrated male Pantaneiro lambs, with a mean body weight of $12.78 \pm 2.03 \mathrm{~kg}$, were randomly assigned to five treatments, with nine replicates, according to the body weight defined for slaughter $(15,20,25,30$, and $35 \mathrm{~kg})$. The age of the animals and the average confinement time for each slaughter group evaluated were as follows: 15 $\mathrm{kg}-2.4$ months and 39 days; $20 \mathrm{~kg}-3.3$ months and 58 days; $25 \mathrm{~kg}-4.2$ months and 88 days; $30 \mathrm{~kg}$ - 5.0 months and 105 days; $35 \mathrm{~kg}-5.3$ months and 115 days. The animals were housed in individual pens $\left(2 \mathrm{~m}^{2}\right)$ with concrete floors covered in wood shavings and equipped with feeding and drinking troughs. At the beginning of the adaptation phase (14 days), all animals were identified by earring tags and dewormed.

The experimental diet was the same for all animals and was based on commercial feed made of ground corn $\left[550 \mathrm{~g} \mathrm{~kg}^{-1}\right.$ of dry matter (DM)], wheat bran $\left(160 \mathrm{~g} \mathrm{~kg}^{-1} \mathrm{DM}\right)$, soybean meal $\left(40 \mathrm{~g} \mathrm{~kg}^{-1} \mathrm{DM}\right)$, urea $\left(20 \mathrm{~g} \mathrm{~kg}^{-1} \mathrm{DM}\right)$, and mineral mix $\left(30 \mathrm{~g} \mathrm{~kg}^{-1}\right.$ 
DM), while oat hay was used as roughage at a ratio of 80:20. The diet was provided twice a day $(07 \mathrm{~h} 00$ and $16 \mathrm{~h} 00$ ) and the consumption was adjusted daily to achieve leftovers of $150 \mathrm{~g} \mathrm{~kg}^{-1}$ of the total amount consumed in the previous day to ensure ad libitum intake. The lambs were slaughtered when the predetermined body weights were reached. Before slaughter, animals were fasted for $16 \mathrm{~h} 00$. After fasting, lambs were stunned by electronarcosis, bled, skinned, gutted, and weighed. Subsequently, the carcasses were cooled in a cold chamber at $4{ }^{\circ} \mathrm{C}$ for $24 \mathrm{~h} 00$. The carcasses were weighed, longitudinally sectioned into two half-carcasses, and separated into cuts. Samples of Semimembranosus (SM), Longissimus lumborum (LL), Gluteobiceps (GB), and Triceps brachii (TB) muscles were collected from both carcasses and stored, as were the cuts, in plastic packaging, labeled, and frozen at $-18{ }^{\circ} \mathrm{C}$.

For instrumental and centesimal analyses, samples of the four muscles (m.) (SM, LL, GB, and TB) were used, and for fatty acid (FA) analysis only the LL m. were used. On the day of the evaluation, the samples were thawed at refrigerator temperature $\left(10{ }^{\circ} \mathrm{C}\right)$ and cut into $2.5 \mathrm{~cm}$-thick steaks using a standardized scale. The $\mathrm{pH}$ was determined after thawing using a previously calibrated digital portable $\mathrm{pH}$ meter (Testo 205, Testo, Lenzkirch, Germany) and introduced directly into the muscle portion of the steaks. The color of the thawed meat was also determined, using a previously calibrated digital colorimeter (Chroma Meter CR-400, Konika Minolta Co., Osaka, Japan) operating in the CIE L*, $a^{*}, b^{*}$ color space, with an aperture size of $8 \mathrm{~mm}$ and using a $\mathrm{D}_{65}$ as illuminant. The analysis measured lightness $\left(\mathrm{L}^{*}\right)$, redness $\left(\mathrm{a}^{*}\right)$, and yellowness $\left(\mathrm{b}^{*}\right)$ in the fresh meat after the samples were exposed to ambient temperature for $30 \mathrm{~min}$.

Water holding capacity (WHC) was determined by the compression method; a sample of approximately $2 \mathrm{~g}$ was subjected to a weight of $2,250 \mathrm{~kg}$ for $5 \mathrm{~min}$ according to the methodology described by Cañeque and Sañudo (2005). The resulting sample was weighed and the amount of water lost was calculated by difference, with the result being expressed as percentage of water retained in relation to the weight of the initial sample.

For cooking loss analysis (CL), the meat samples were roasted in an electric oven pre-heated to $170{ }^{\circ} \mathrm{C}$ until the internal temperature reached 70 ${ }^{\circ} \mathrm{C}$. The weights of the samples before and after cooking were used to calculate total loss, expressed as percentage (OSÓRIO et al., 2008). The same samples were used after cooling to determine shear force (SF), as described by Osório et al. (2008). Six longitudinal strips of muscle fibers were taken using a cylindrical steel sampler coupled to a $1 \mathrm{~mm}$ Warner Bratzler blade (TA-XT Plus, Stable Micro Systems Ltd., Godalming, UK) to determine the force required to cut each cylinder transversally. The mean force needed to cut the cylinders was calculated and expressed in kilogram-force (kgf) to represent the shear force of each muscle.

For analysis of the chemical composition of the meat, samples of all the muscles (SM, LL, $\mathrm{GB}$, and $\mathrm{TB}$ ) were thawed in a refrigerator at $10{ }^{\circ} \mathrm{C}$, homogenized in a food processor until a homogeneous mass was obtained, and pre-dried in a forced-air circulation oven at $55^{\circ} \mathrm{C}$ for $72 \mathrm{~h} 00$. They were then ground in a mill, packaged, and identified. Analyses of moisture, protein, fat, and ash were carried out according to AOAC recommendations (AOAC, 2010).

For determination of the fatty acid (FA) profile, the frozen LL m. were lyophilized for $72 \mathrm{~h} 00$ and total lipids were extracted according to Bligh and Dyer (1959). Approximately $3 \mathrm{~g}$ of lyophilized sample was transferred to a $125 \mathrm{~mL}$ Erlenmeyer flask and $10 \mathrm{~mL}$ chloroform, $20 \mathrm{~mL}$ methanol, and $8 \mathrm{~mL}$ of distilled water was added. The flask was then placed in a platform shaker for $30 \mathrm{~min}$. After stirring, $10 \mathrm{~mL}$ chloroform and $10 \mathrm{~mL} 1.5 \%$ sodium sulfate were added and the flasks were placed for a further $2 \mathrm{~min}$ on the platform shaker. The material was filtered through quantitative filter paper and 
transferred to a $50 \mathrm{~mL}$ Falcon tube. After the layers were separated, the upper, methanoic layer was discarded. From the remaining filtrate, $10 \mathrm{~mL}$ was transferred to previously tared $50 \mathrm{~mL}$ beakers. The beakers were placed in a forced-air oven for $24 \mathrm{~h} 00$ at $55{ }^{\circ} \mathrm{C}$ to evaporate the solvent and then cooled in a desiccator. For triglyceride transesterification, approximately $50 \mathrm{mg}$ of the lipid matter extracted were transferred to a $15 \mathrm{~mL}$ Falcon tube and $2 \mathrm{~mL}$ n-heptane were added. The flasks were placed onto a platform shaker for complete dissolution of the grease material and then $2 \mathrm{~mL} 2 \mathrm{~mol} / \mathrm{L} \mathrm{KOH}$ in methanol were added. This mixture was agitated for approximately $5 \mathrm{~min}$, and, after phase separation, $1 \mathrm{~mL}$ of the upper phase (heptane and fatty acid methyl esters) was transferred to $1.5 \mathrm{~mL}$ Eppendorf tubes. The flasks were hermetically sealed, protected from light, and stored in a freezer at $-18{ }^{\circ} \mathrm{C}$ for later chromatographic analyses. The fatty acid profile was determined by gas chromatography using a gas chromatograph (GC-2010 Plus, Shimadzu, Kyoto, Japan) with a flame ionization detector. A $100 \mathrm{~m} \times 0.25 \mathrm{~mm} \times 0.20 \mu \mathrm{m}$ fused silica capillary column DB-5 (J and W, Folsom, California, USA) was employed for elution. Oven temperature was programmed to start at $100{ }^{\circ} \mathrm{C}$ and was maintained for $1 \mathrm{~min}$, after which it was raised to $170{ }^{\circ} \mathrm{C}$ at $6.5{ }^{\circ} \mathrm{C} / \mathrm{min}$. The temperature was then raised to $215^{\circ} \mathrm{C}$ at $2.75{ }^{\circ} \mathrm{C} / \mathrm{min}$ and kept at that level for 30 min. Finally, it was raised to $230{ }^{\circ} \mathrm{C}$ at $40{ }^{\circ} \mathrm{C} / \mathrm{min}$. Injector and detector temperatures were 270 and 280 ${ }^{\circ} \mathrm{C}$, respectively. A sample of $0.5 \mu \mathrm{L}$ was injected in split mode using nitrogen as the carrier gas at a flow rate of $1 \mathrm{~mL} / \mathrm{min}$. The fatty acid methyl esters were identified by comparing the holding times of the compounds in the sample with the standards (Sigma) eluted under the same conditions.

Atherogenicity index $(\mathrm{AI})=[(\mathrm{C} 12: 0+(4 \times$ $\mathrm{C} 14: 0)+\mathrm{C} 16: 0)] /(\Sigma \mathrm{MUFA}+\Sigma \omega 6+\Sigma \omega 3)$ and thrombogenicity index $(\mathrm{TI})=(\mathrm{C} 14: 0+\mathrm{C} 16: 0$ $+\mathrm{C} 18: 0) /[(0.5 \times \Sigma$ MUFA $)+(0.5 \times \Sigma \omega 6+(3 \times$
$\Sigma \omega 3)+(\Sigma \omega 3 / \Sigma \omega 6)]$ were determined according to Ulbricht and Southgate (1991), whereas the proportion between hypocholesterolemic and hypercholesterolemic fatty acids $(\mathrm{h} / \mathrm{H})=(\mathrm{C} 18: 1$ cis 9 $+\mathrm{C} 18: 2 \omega 6+20: 4 \omega 6+\mathrm{C} 18: 3 \omega 3+\mathrm{C} 20: 5 \omega 3$ $+\mathrm{C} 22: 5 \omega 3+\mathrm{C} 22: 6 \omega 3) /(\mathrm{C} 14: 0+\mathrm{C} 16: 0)$, was determined according to Santos-Silva et al. (2002).

Activity of $\Delta^{9}$-desaturase enzymes was determined according to Malau-Aduli et al. (1997): $\Delta^{9}$-desaturase $16=100[(\mathrm{C} 16: 1$ cis 9$) /(\mathrm{C} 16: 1$ cis9 + $\mathrm{C} 16: 0)]$ and $\Delta^{9}$-desaturase $18=100[(\mathrm{C} 18: 1$ cis9 $) /$ $(\mathrm{C} 18: 1 \mathrm{cis} 9+\mathrm{C} 18: 0)]$.

Before the statistical analysis, the assumptions of normal distribution and homoscedasticity for all the variables were verified. All the statistical analyses were performed using polynomial regression of the statistical software XLSTAT (2014). The following mathematical model was used:

$$
\mathrm{Y}_{i j}=\beta_{0}+\beta_{1} x_{i}+\beta_{2} x_{i}^{2}+a j+\varepsilon_{i j}
$$

where $\mathrm{Y}_{i j}$ represents the variable response (dependent variable) of $j$-th replicate on $i$-th body weight; $\beta_{0}, \beta_{1}$, and $\beta_{2}$ represent the intercept, linear regression, and quadratic regression coefficient, respectively; $x_{i}=$ independent variable (body weight); $\alpha_{j}=$ deviations from the regression; and $\varepsilon i=$ the residual random error. The most adequate model for each variable was selected based on the significance of the linear and quadratic coefficients, using a 0.05 significance level.

\section{Results and Discussion}

No effect $(\mathrm{P}>0.05)$ of the different body weights was observed on the instrumental characteristics of the LL m. (Table 1), CL, or b* index. However, a significant effect $(\mathrm{P}<0.05)$ was observed on $\mathrm{pH}$, WHC, SF, L*, and $\mathrm{a}^{*}$ of the SM m. (Table 1), as well as on $\mathrm{pH}$ and $\mathrm{L}^{*}$ values of the TB $\mathrm{m}$., and $\mathrm{L}^{*}$ value of the GB m. (Table 2). 
Table 1. Qualitative characteristics of Semimembranous and Longissimus lumborum muscles from Pantaneiro lambs at different body weights.

\begin{tabular}{|c|c|c|c|c|c|c|c|}
\hline \multirow{2}{*}{ Variable } & \multicolumn{5}{|c|}{ Body weight $(\mathrm{kg})$} & \multirow{2}{*}{$\mathrm{CV}(\%)$} & \multirow{2}{*}{$P$} \\
\hline & 15 & 20 & 25 & 30 & 35 & & \\
\hline \multicolumn{8}{|c|}{ Semimembranosus } \\
\hline $\mathrm{pH}^{1}$ & $5.58 \pm 0.08$ & $5.60 \pm 0.08$ & $5.64 \pm 0.13$ & $5.63 \pm 0.08$ & $5.69 \pm 0.07$ & 1.66 & 0.007 \\
\hline $\mathrm{WHC}^{2}\left(\mathrm{~g} \mathrm{~kg}^{-1}\right)$ & $745.3 \pm 33.1$ & $753.3 \pm 49.2$ & $780.4 \pm 42.5$ & $797.3 \pm 28.1$ & $799.3 \pm 31.4$ & 5.47 & $<0.001$ \\
\hline $\mathrm{CL}\left(\mathrm{g} \mathrm{kg}^{-1}\right)$ & $390.1 \pm 40.0$ & $354.3 \pm 50.5$ & $337.8 \pm 46.8$ & $364.6 \pm 28.0$ & $357.0 \pm 38.5$ & 11.61 & 0.264 \\
\hline $\mathrm{SF}^{3}(\mathrm{kgf})$ & $3.96 \pm 1.08$ & $4.31 \pm 1.21$ & $3.58 \pm 1.03$ & $3.15 \pm 1.21$ & $2.64 \pm 0.49$ & 32.77 & 0.002 \\
\hline $\mathrm{L}^{* 4}$, lightness & $38.36 \pm 2.59$ & $39.25 \pm 2.77$ & $39.04 \pm 2.23$ & $37.57 \pm 2.64$ & $35.63 \pm 1.89$ & 7.07 & 0.010 \\
\hline$a^{* 5}$, redness & $16.56 \pm 2.89$ & $17.83 \pm 2.95$ & $18.24 \pm 2.96$ & $19.56 \pm 3.24$ & $19.21 \pm 3.26$ & 17.04 & 0.039 \\
\hline b yellowness & $6.42 \pm 1.83$ & $6.65 \pm 1.15$ & $7.60 \pm 1.82$ & $7.58 \pm 1.57$ & $7.39 \pm 1.91$ & 23.55 & 0.158 \\
\hline \multicolumn{8}{|c|}{ Longissimus lumborum } \\
\hline $\mathrm{pH}$ & $5.59 \pm 0.09$ & $5.61 \pm 0.07$ & $5.63 \pm 0.09$ & $5.63 \pm 0.08$ & $5.64 \pm 0.05$ & 1.36 & 0.224 \\
\hline WHC $\left(\mathrm{g} \mathrm{kg}^{-1}\right)$ & $778.0 \pm 32.7$ & $769.2 \pm 34.3$ & $786.5 \pm 38.2$ & $779.5 \pm 32.5$ & $781.1 \pm 30.7$ & 4.20 & 0.502 \\
\hline $\mathrm{CL}\left(\mathrm{g} \mathrm{kg}^{-1}\right)$ & $341.4 \pm 71.8$ & $374.6 \pm 53.0$ & $355.4 \pm 40.9$ & $327.9 \pm 41.3$ & $316.9 \pm 25.1$ & 14.86 & 0.088 \\
\hline $\mathrm{SF}(\mathrm{kgf})$ & $3.21 \pm 1.32$ & $4.07 \pm 1.24$ & $3.83 \pm 1.17$ & $3.44 \pm 1.23$ & $2.48 \pm 0.49$ & 35.61 & 0.119 \\
\hline $\mathrm{L}^{*}$, lightness & $39.49 \pm 3.90$ & $38.77 \pm 3.25$ & $39.57 \pm 2.93$ & $38.81 \pm 3.12$ & $37.54 \pm 2.10$ & 7.87 & 0.230 \\
\hline$a^{*}$, redness & $16.05 \pm 2.73$ & $17.73 \pm 3.06$ & $16.54 \pm 2.67$ & $18.60 \pm 3.75$ & $18.87 \pm 3.11$ & 17.95 & 0.083 \\
\hline $\mathrm{b}^{*}$, yellowness & $6.21 \pm 2.41$ & $6.09 \pm 1.76$ & $5.89 \pm 1.65$ & $7.65 \pm 2.24$ & $7.08 \pm 1.90$ & 30.93 & 0.175 \\
\hline
\end{tabular}

$\mathrm{WHC}=$ water holding capacity; $\mathrm{CL}=$ cooking loss; $\mathrm{SF}=$ shear force.

${ }^{1} \mathrm{y}=5.4939+0.005189 \mathrm{x}\left(\mathrm{R}^{2}=0.16\right) ;{ }^{2} \mathrm{y}=62.0421+0.9254 \mathrm{x}-0.01178 \mathrm{x}^{2}\left(\mathrm{R}^{2}=0.28\right) ;{ }^{3} \mathrm{y}=5.4443-0.07406 \mathrm{x}\left(\mathrm{R}^{2}=0.21\right) ;{ }^{4} \mathrm{y}=$ $28.1761+0.8950 \mathrm{x}-0.01895 \mathrm{x}^{2}\left(\mathrm{R}^{2}=0.20\right) ;{ }^{5} \mathrm{y}=8.2427+0.5456 \mathrm{x}-0.006482 \mathrm{x}^{2}\left(\mathrm{R}^{2}=0.22\right)$.

Table 2. Qualitative characteristics of Gluteobiceps and Triceps brachii muscles from Pantaneiro lambs at different body weights.

\begin{tabular}{|c|c|c|c|c|c|c|c|}
\hline \multirow{2}{*}{ Variable } & \multicolumn{5}{|c|}{ Body weight (kg) } & \multirow{2}{*}{ CV $(\%)$} & \multirow{2}{*}{$P$} \\
\hline & 15 & 20 & 25 & 30 & 35 & & \\
\hline \multicolumn{8}{|c|}{ Gluteobiceps } \\
\hline $\mathrm{pH}$ & $5.61 \pm 0.10$ & $5.65 \pm 0.09$ & $5.69 \pm 0.12$ & $5.63 \pm 0.07$ & $5.67 \pm 0.06$ & 1.58 & 0.283 \\
\hline WHC $\left(\mathrm{g} \mathrm{kg}^{-1}\right)$ & $783.8 \pm 36.4$ & $803.8 \pm 44.4$ & $770.3 \pm 57.0$ & $814.4 \pm 59.9$ & $798.2 \pm 37.9$ & 6.10 & 0.441 \\
\hline $\mathrm{CL}\left(\mathrm{g} \mathrm{kg}^{-1}\right)$ & $348.8 \pm 39.3$ & $356.4 \pm 38.7$ & $358.3 \pm 36.0$ & $322.2 \pm 51.0$ & $328.2 \pm 47.9$ & 12.73 & 0.143 \\
\hline SF (kgf) & $2.60 \pm 1.25$ & $2.73 \pm 0.63$ & $2.74 \pm 0.75$ & $2.27 \pm 0.42$ & $2.13 \pm 0.32$ & 30.27 & 0.106 \\
\hline $\mathrm{L}^{6}$, lightness & $40.98 \pm 1.73$ & $41.47 \pm 2.38$ & $41.58 \pm 2.01$ & $39.38 \pm 1.89$ & $39.63 \pm 2.05$ & 5.28 & 0.041 \\
\hline$a^{*}$, redness & $15.33 \pm 3.99$ & $16.45 \pm 3.61$ & $16.21 \pm 3.17$ & $18.04 \pm 3.59$ & $17.87 \pm 3.38$ & 21.15 & 0.101 \\
\hline $\mathrm{b}^{*}$, yellowness & $6.34 \pm 3.00$ & $5.88 \pm 2.50$ & $6.00 \pm 2.17$ & $6.92 \pm 2.08$ & $6.31 \pm 1.98$ & 36.48 & 0.757 \\
\hline \multicolumn{8}{|c|}{ Triceps brachii } \\
\hline $\mathrm{pH}^{7}$ & $5.72 \pm 0.08$ & $5.73 \pm 0.07$ & $5.82 \pm 0.13$ & $5.82 \pm 0.08$ & $5.82 \pm 0.05$ & 1.66 & 0.003 \\
\hline WHC $\left(\mathrm{g} \mathrm{kg}^{-1}\right)$ & $790.4 \pm 38.6$ & $779.7 \pm 71.7$ & $778.7 \pm 59.0$ & $846.0 \pm 48.2$ & $804.5 \pm 30.0$ & 6.91 & 0.116 \\
\hline $\mathrm{CL}\left(\mathrm{g} \mathrm{kg}^{-1}\right)$ & $400.6 \pm 28.4$ & $375.0 \pm 51.6$ & $361.5 \pm 77.1$ & $350.0 \pm 56.6$ & $370.8 \pm 53.9$ & 15.01 & 0.166 \\
\hline SF (kgf) & $2.37 \pm 0.85$ & $2.44 \pm 0.66$ & $2.59 \pm 0.48$ & $2.29 \pm 0.40$ & $2.73 \pm 0.29$ & 22.87 & 0.267 \\
\hline $\mathrm{L}^{* 8}$, lightness & $43.47 \pm 3.48$ & $43.87 \pm 3.72$ & $43.20 \pm 3.12$ & $40.73 \pm 2.23$ & $41.30 \pm 1.53$ & 7.22 & 0.020 \\
\hline
\end{tabular}


continuation

\begin{tabular}{lccccccc}
$\mathrm{a}^{*}$, redness & $15.66 \pm 4.13$ & $17.38 \pm 4.40$ & $16.18 \pm 3.75$ & $18.18 \pm 4.21$ & $17.19 \pm 4.80$ & 24.66 & 0.455 \\
$\mathrm{~b}^{*}$, yellowness & $6.89 \pm 2.21$ & $6.58 \pm 2.21$ & $6.06 \pm 1.82$ & $6.17 \pm 3.08$ & $5.92 \pm 2.82$ & 37.66 & 0.260 \\
\hline
\end{tabular}

$\mathrm{WHC}=$ water holding capacity; $\mathrm{CL}=$ cooking loss; $\mathrm{SF}=$ shear force.

${ }^{6} \mathrm{y}=37.5480+0.3532 \mathrm{x}-0.008445 \mathrm{x}^{2}\left(\mathrm{R}^{2}=0.13\right) ;{ }^{7} \mathrm{y}=5.3821+0.02639 \mathrm{x}-0.0003905 \mathrm{x}^{2}\left(\mathrm{R}^{2}=0.22\right) ;{ }^{8} \mathrm{y}=46.9208-0.1949 \mathrm{x}+$ $0.0008901 x^{2}\left(R^{2}=0.12\right)$.

The $\mathrm{pH}$ values ranged from 5.58 to 5.69 for the SM m. (Table 1), and 5.72 to 5.82 for the TB $\mathrm{m}$. (Table 2), indicating that the animals were not stressed at the time of slaughter. Costa et al. (2014), working with Santa Inês and F1 Santa Inês $\times$ Dorper lambs, observed a mean final $\mathrm{pH}$ of 5.68 for the $\mathrm{SM} \mathrm{m}$. and 5.64 for the semitendinosus muscle; meanwhile, Ferrão et al. (2009), studying the meat quality of Santa Inês lambs, recorded $\mathrm{pH}$ values ranging from 5.53 to 5.57 for the $\mathrm{SM} \mathrm{m}$. The $\mathrm{pH}$ values recorded in both studies are similar to those in the present study and, although we observed a slight tendency of this parameter to increase, the quality of the meat was not compromised and the values were within the normally accepted range for sheep meat (ZEOLA et al., 2007).

The WHC of the SM m. displayed an increasing trend with increasing body weight of the animals (Table 1). Jacob and Pethick (2014) considered $\mathrm{pH}$ to be the main factor affecting water retention capacity, with minimum retention capacity at the isoelectric point of meat proteins ( $\mathrm{pH}$ 5.0-5.5). In this study, we observed that animals with meat of lower $\mathrm{pH}$ (5.58) and lower body weight $(15 \mathrm{~kg})$ presented a reduced WHC (745.3 $\left.\mathrm{g} \mathrm{kg}^{-1}\right)$ compared to those with higher body weight $(35 \mathrm{~kg})(799.3$ $\left.\mathrm{g} \mathrm{kg}^{-1}\right)$. This agrees with the results of Jian-bin et al. (2015) who also reported reduced WHC (99.5 $\left.\mathrm{g} \mathrm{kg}^{-1}\right)$ for lighter Oula lambs $(25 \mathrm{~kg})$ at different slaughter weights. The lower WHC of the meat is a detrimental characteristic as it implies loss of nutritional value through exudate release, resulting in drier and less tender meat (MONTE et al., 2012).

In relation to the $\mathrm{SF}$, a downward trend was observed with increasing body weight in the SM m. (Table 1), that is, lighter animals had tougher meat compared to heavier ones. This may be due to the positive correlation between intramuscular fat and meat tenderness. The average SF found in the current experiment ranged from 2.64 to 4.31 kgf, indicating that the meat of Pantaneiro lambs is moderately tender, as also reported by Boleman et al. (1997). Our results are in accordance with Santos et al. (2015) who also observed a lower SF value $\left(5.0 \mathrm{~kg} / \mathrm{cm}^{2}\right)$ in heavier animals while analyzing meat quality of Mirandês lambs slaughtered at two carcass weights. However, the opposite was recorded by Jian-bin et al. (2015) working with Oula lambs at different slaughter weights, where heavier animals $(45 \mathrm{~kg})$ presented tougher meat $\left(3.48 \mathrm{~kg} / \mathrm{cm}^{2}\right)$ than lighter ones $(25 \mathrm{~kg})(3.06 \mathrm{~kg} /$ $\mathrm{cm}^{2}$ ). According to the authors, this may have been due to older sheep having muscle fibers of larger diameter and with a greater number of cross-links, resulting in tougher meat.

With regard to meat color, the $\mathrm{L}^{*}$ value of the SM (Table 1), GB, and TB (Table 2) muscles decreased with increasing body weight of the lambs. According to Moloney et al. (2012), muscles of younger animals have less fat and a higher percentage of water, which promotes meat lightness. For sheep, variations for $\mathrm{L}^{*}$ ranging between 30.03 to 49.47 have been reported in the literature (SAÑUDO et al., 2000). Our results are in agreement with Jianbin et al. (2015) who observed a higher lightness index in Oula lambs of lower body weight $(25 \mathrm{~kg})$ at slaughter, similar to that reported by Abdullah and Qudsieh (2009) when analyzing Awassi ram lambs with different slaughter weights.

The SM m. a* index increased significantly $(\mathrm{P}<0.05)$ with increased weight (Table 1$)$, which may be explained by the higher concentration of myoglobin present in large muscle masses. In this study, the average redness values ranged from 16.56 
to 19.56 , with means ranging from 8.24 to 23.53 having previously been reported for sheep (SOUZA et al., 2004); Jian-bin et al. (2015), working with Oula lambs at different slaughter weights, as well as Polidori et al. (2017), working with Fabrianese lambs of different ages at slaughter, also found a darker meat in heavier lambs.

In contrast, body weight did not influence $(\mathrm{P}>0.05)$ the chemical composition of the SMm., and no effect $(\mathrm{P}>0.05)$ was observed on the protein or ash content of the meat (Table 3). The moisture content of TB $\mathrm{m}$. tended to decrease, while the fat content of LL, GB, and TB m. tended to increase (Table 3). This is likely due to the increase in intramuscular fat storage that takes place with higher body weight at slaughter (LOPES et al., 2012a) and the results obtained here satisfy the assumption that the lipid content has a negative correlation with moisture and protein (PFLANZER; FELÍCIO, 2011). According to Madruga et al. (2006), the chemical composition of sheep meat includes mean values of $750.0 \mathrm{~g} \mathrm{~kg}^{-1}$ for moisture, $190.0 \mathrm{~g} \mathrm{~kg}^{-1}$ for protein, $40.0 \mathrm{~g} \mathrm{~kg}^{-1}$ for fat, and $10.0 \mathrm{~g} \mathrm{~kg}^{-1}$ for ash, with possible variations. In our study, the chemical composition presented marginally lower average values for moisture (727.4 to $742.3 \mathrm{~g} \mathrm{~kg}^{-1}$ for TB m.) and higher for fat (14.6 g $\mathrm{kg}^{-1}$ for LL m. to $62.5 \mathrm{~g} \mathrm{~kg}^{-1}$ for TB m.). Our results are consistent with the findings of Abdullah and Qudsieh (2009), Polidori et al. (2017), and Jian-bin et al. (2015) which observed a marked reduction in the moisture content and increase in fat levels with increasing body weight of animals.

Table 3. Chemical composition ( $\left.\mathrm{g} \mathrm{kg}^{-1} \mathrm{DM}\right)$ of Pantaneiro lamb meat at different body weights.

\begin{tabular}{|c|c|c|c|c|c|c|c|}
\hline \multirow{2}{*}{ Variable } & \multicolumn{5}{|c|}{ Body weight $(\mathrm{kg})$} & \multirow{2}{*}{ CV $(\%)$} & \multirow{2}{*}{$P$} \\
\hline & 15 & 20 & 25 & 30 & 35 & & \\
\hline \multicolumn{8}{|c|}{ Semimembranosus } \\
\hline Moisture & $741.0 \pm 13.0$ & $747.3 \pm 9.2$ & $738.7 \pm 14.6$ & $739.4 \pm 7.3$ & $739.1 \pm 8.7$ & 1.47 & 0.159 \\
\hline Protein & $189.6 \pm 12.8$ & $185.4 \pm 31.3$ & $189.1 \pm 20.7$ & $197.2 \pm 11.5$ & $198.9 \pm 10.9$ & 9.86 & 0.138 \\
\hline Fat & $20.7 \pm 10.5$ & $28.5 \pm 7.0$ & $36.3 \pm 10.9$ & $33.3 \pm 12.0$ & $25.2 \pm 7.7$ & 37.93 & 0.280 \\
\hline Ash & $14.5 \pm 2.3$ & $13.9 \pm 2.0$ & $12.8 \pm 1.9$ & $13.2 \pm 2.6$ & $13.2 \pm 2.4$ & 16.43 & 0.131 \\
\hline \multicolumn{8}{|c|}{ Longissimus lumborum } \\
\hline Moisture & $744.1 \pm 14.4$ & $743.8 \pm 11.4$ & $747.0 \pm 15.2$ & $737.6 \pm 9.3$ & $736.2 \pm 13.3$ & 1.75 & 0.054 \\
\hline Protein & $199.7 \pm 14.0$ & $185.7 \pm 19.9$ & $192.5 \pm 16.9$ & $198.1 \pm 21.9$ & $197.8 \pm 13.4$ & 8.98 & 0.679 \\
\hline Fat $^{1}$ & $14.6 \pm 6.9$ & $25.9 \pm 10.5$ & $27.8 \pm 8.4$ & $34.8 \pm 16.1$ & $32.8 \pm 9.7$ & 46.17 & $<0.001$ \\
\hline Ash & $12.7 \pm 1.2$ & $12.7 \pm 1.6$ & $11.7 \pm 1.2$ & $11.5 \pm 0.9$ & $12.4 \pm 1.6$ & 11.15 & 0.128 \\
\hline \multicolumn{8}{|c|}{ Gluteobiceps } \\
\hline Moisture & $741.5 \pm 17.7$ & $747.7 \pm 8.0$ & $746.3 \pm 12.7$ & $731.9 \pm 22.5$ & $741.5 \pm 16.4$ & 2.18 & 0.224 \\
\hline Protein & $192.9 \pm 12.2$ & $181.9 \pm 24.2$ & $180.8 \pm 19.8$ & $192.8 \pm 13.8$ & $181.3 \pm 19.3$ & 9.96 & 0.637 \\
\hline $\mathrm{Fat}^{2}$ & $23.3 \pm 12.7$ & $44.6 \pm 25.0$ & $32.6 \pm 15.9$ & $50.8 \pm 27.4$ & $42.9 \pm 14.6$ & 55.08 & 0.040 \\
\hline Ash & $12.5 \pm 1.5$ & $12.2 \pm 2.4$ & $11.9 \pm 1.3$ & $11.4 \pm 1.6$ & $11.5 \pm 1.9$ & 14.68 & 0.084 \\
\hline \multicolumn{8}{|c|}{ Triceps brachii } \\
\hline Moisture $^{3}$ & $740.8 \pm 17.3$ & $742.3 \pm 13.1$ & $737.3 \pm 16.1$ & $729.2 \pm 20.5$ & $727.4 \pm 24.0$ & 2.55 & 0.025 \\
\hline Protein & $187.2 \pm 27.8$ & $172.5 \pm 26.9$ & $179.7 \pm 10.8$ & $185.8 \pm 13.1$ & $182.4 \pm 15.3$ & 10.95 & 0.865 \\
\hline $\mathrm{Fat}^{4}$ & $29.2 \pm 20.4$ & $57.1 \pm 23.8$ & $62.5 \pm 23.3$ & $57.4 \pm 29.2$ & $56.8 \pm 25.0$ & 49.93 & 0.039 \\
\hline Ash & $12.0 \pm 1.0$ & $11.3 \pm 1.9$ & $11.3 \pm 1.4$ & $11.4 \pm 0.9$ & $11.2 \pm 1.0$ & 10.99 & 0.264 \\
\hline
\end{tabular}

$\mathrm{DM}=$ Dry matter.

${ }^{1} \mathrm{y}=-5.3207+0.5575 \mathrm{x}-0.008817 \mathrm{x}^{2}\left(\mathrm{R}^{2}=0.38\right) ;{ }^{2} \mathrm{y}=-1.8159+0.3625 \mathrm{x}-0.005135 \mathrm{x}^{2}\left(\mathrm{R}^{2}=0.11\right) ;{ }^{3} \mathrm{y}=77.3431-0.2127 \mathrm{x}+$ $0.002345 \mathrm{x}^{2}\left(\mathrm{R}^{2}=0.12\right) ;{ }^{4} \mathrm{y}=-12.1783+1.2986 \mathrm{x}-0.02240 \mathrm{x}^{2}\left(\mathrm{R}^{2}=0.25\right)$. 
The different body weights influenced $(\mathrm{P}<0.05)$ the content of myristic (C14:0), palmitic (C16:0), margaric (C17:0), stearic (C18:0), oleic (C18:1n-9), and linoleic (C18:2n-6) fatty acids (FAs). Other fatty acids were not affected $(\mathrm{P}>0.05)$ by body weight (Table 4).

The increase in body weight of the lambs led to an increase in myristic (C14:0) and palmitic (C16:0) FA content (Table 4). This confirms data from other studies, where greater amount of $\mathrm{C} 14: 0$ and $\mathrm{C} 16: 0$ were reported for the intramuscular fat of older and heavier lambs (D'ALESSANDRO et al., 2015; DELLA MALVA et al., 2016), which also displayed a less favorable FA profile. This is likely due to these FAs having recognized hypercholesterolemic characteristics, which can increase the risk of cardiovascular diseases (CALDER, 2015). In this regard, the FA profile of lighter lambs was superior compared to heavier lambs.

Table 4. Fatty acid composition of Longissimus lumborum muscles ( $\mathrm{g} \mathrm{kg}^{-1}$ fat) from Pantaneiro lambs at different body weights.

\begin{tabular}{|c|c|c|c|c|c|c|c|}
\hline \multirow{2}{*}{ Fatty acid } & \multicolumn{5}{|c|}{ Body weights } & \multirow{2}{*}{$\mathrm{CV}(\%)$} & \multirow{2}{*}{$P$} \\
\hline & 15 & 20 & 25 & 30 & 35 & & \\
\hline \multicolumn{8}{|l|}{ Saturated fatty acids } \\
\hline C10:0, capric & $1.2 \pm 0.1$ & $1.1 \pm 0.0$ & $1.1 \pm 0.1$ & $1.1 \pm 0.1$ & $1.1 \pm 0.1$ & 7,22 & 0.222 \\
\hline $\mathrm{C} 12: 0$, lauric & $1.2 \pm 0.1$ & $1.2 \pm 0.1$ & $1.1 \pm 0.1$ & $1.2 \pm 0.0$ & $1.2 \pm 0.1$ & 5,76 & 0.530 \\
\hline $\mathrm{C} 14: 0^{1}$, myristic & $23.9 \pm 0.2$ & $25.6 \pm 0.3$ & $27.5 \pm 0.4$ & $28.7 \pm 0.2$ & $29.7 \pm 0.2$ & 7,80 & $<0.0001$ \\
\hline C15:0, pentadecanoic & $1.9 \pm 0.1$ & $2.0 \pm 0.1$ & $1.6 \pm 0.2$ & $2.0 \pm 0.2$ & $2.0 \pm 0.1$ & 11,86 & 0.401 \\
\hline $\mathrm{C} 16: 0^{2}$, palmitic & $229.2 \pm 0.5$ & $239.9 \pm 1.2$ & $250.7 \pm 0.8$ & $259.5 \pm 0.6$ & $269.7 \pm 1.1$ & 5,77 & $<0.0001$ \\
\hline $\mathrm{C} 17: 0^{3}$, margaric & $15.7 \pm 0.2$ & $16.2 \pm 0.3$ & $16.5 \pm 0.3$ & $18.0 \pm 0.7$ & $19.0 \pm 0.5$ & 7,63 & $<0.0001$ \\
\hline $\mathrm{C} 18: 0^{4}$, stearic & $171.0 \pm 0.5$ & $162.5 \pm 0.2$ & $160.6 \pm 0.3$ & $160.4 \pm 1.0$ & $152.2 \pm 0.4$ & 3,76 & $<0.0001$ \\
\hline C20:0, arachidic & $1.1 \pm 0.0$ & $1.1 \pm 0.1$ & $1.1 \pm 0.1$ & $1.1 \pm 0.0$ & $1.1 \pm 0.0$ & 5,48 & 0.272 \\
\hline \multicolumn{8}{|c|}{ Monounsaturated fatty acids } \\
\hline C14:1, myristoleic & $1.1 \pm 0.0$ & $1.0 \pm 0.0$ & $1.0 \pm 0.0$ & $1.0 \pm 0.1$ & $1.0 \pm 0.1$ & 4,76 & 0.335 \\
\hline C16:1, palmitoleic & $16.5 \pm 0.1$ & $16.7 \pm 0.3$ & $16.1 \pm 0.2$ & $16.5 \pm 0.3$ & $16.7 \pm 0.1$ & 1,89 & 0.800 \\
\hline C18:1n-95, oleic & $464.3 \pm 0.4$ & $458.9 \pm 1.2$ & $450.4 \pm 0.1$ & $447.6 \pm 1.1$ & $440.4 \pm 0.3$ & 1,89 & $<0.0001$ \\
\hline C20:1n-9, eicosenoic & $1.0 \pm 0.0$ & $1.0 \pm 0.0$ & $1.0 \pm 0.0$ & $1.0 \pm 0.1$ & $1.0 \pm 0.1$ & 4,45 & 0.095 \\
\hline \multicolumn{8}{|c|}{ Polyunsaturated fatty acids } \\
\hline C18:2n- $6^{6}$, linoleic & $39.1 \pm 0.4$ & $39.5 \pm 0.6$ & $37.2 \pm 0.6$ & $35.6 \pm 0.6$ & $33.4 \pm 0.2$ & 6,29 & $<0.0001$ \\
\hline C18:2, CLA & $4.5 \pm 0.1$ & $4.8 \pm 0.2$ & $5.4 \pm 0.3$ & $4.5 \pm 0.2$ & $4.6 \pm 0.2$ & 8,48 & 0.806 \\
\hline C18:3n-3, linolenic & $1.9 \pm 0.1$ & $1.7 \pm 0.1$ & $2.0 \pm 0.0$ & $1.9 \pm 0.2$ & $1.9 \pm 0.1$ & 8,29 & 0.099 \\
\hline $\mathrm{C} 20: 2$, eicosadienoic & $1.1 \pm 0.1$ & $1.0 \pm 0.0$ & $1.0 \pm 0.1$ & $1.0 \pm 0.1$ & $1.0 \pm 0.1$ & 4,79 & 0.723 \\
\hline$C 20: 3 n-6^{*}$ & $1.0 \pm 0.1$ & $1.0 \pm 0.1$ & $1.0 \pm 0.0$ & $1.0 \pm 0.1$ & $1.0 \pm 0.1$ & 4,72 & 0.852 \\
\hline$C 20: 3 n-3^{* *}$ & $14.8 \pm 0.3$ & $14.9 \pm 0.3$ & $13.4 \pm 0.3$ & $13.6 \pm 0.8$ & $14.7 \pm 0.2$ & 5,29 & 0.079 \\
\hline C20:4n-6, arachidonic & $2.0 \pm 0.2$ & $1.7 \pm 0.1$ & $1.9 \pm 0.2$ & $1.9 \pm 0.2$ & $1.9 \pm 0.1$ & 9,12 & 0.807 \\
\hline$C 20: 5 n-3^{* * *}$ & $1.0 \pm 0.1$ & $1.0 \pm 0.0$ & $1.0 \pm 0.0$ & $1.0 \pm 0.1$ & $1.0 \pm 0.1$ & 4,36 & 0.841 \\
\hline
\end{tabular}

*(di-homo- $\gamma$-linolenic); ${ }^{* *}($ di-homo- $\alpha$-linolenic $) ;{ }^{* * *}($ eicosapentaenoic $)$.

${ }^{1} \mathrm{y}=1.4689+0.06948 \mathrm{x}-0.0007781 \mathrm{x}^{2}\left(\mathrm{R}^{2}=0.96\right) ;{ }^{2} \mathrm{y}=18.2939+0.3256 \mathrm{x}-0.002417 \mathrm{x}^{2}\left(\mathrm{R}^{2}=0.97\right) ;{ }^{3} \mathrm{y}=1.4948-$ $0.0008118 \mathrm{x}+0.0003249 \mathrm{x}^{2}\left(\mathrm{R}^{2}=0.81\right) ; \mathrm{y}=18.6574-0.1189 \mathrm{x}+0.0007723 \mathrm{x}^{2}\left(\mathrm{R}^{2}=0.86\right) ;{ }^{5} \mathrm{y}=49.2305-0.1972 \mathrm{x}+$ $0.001536 \mathrm{x}^{2}\left(\mathrm{R}^{2}=0.96\right) ;{ }^{6} \mathrm{y}=4.0051+0.008982 \mathrm{x}-0.0007523 \mathrm{x}^{2}\left(\mathrm{R}^{2}=0.91\right)$. 
The significant effect $(\mathrm{P}<0.05)$ of body weight on the higherconcentration of $\mathrm{C}$ 17:0 found in Pantaneiro lambs of $35 \mathrm{~kg}$ at slaughter may be attributable to the development of ruminal microflora and the increasing consumption of concentrated feed, as odd-chain FAs are generated from bacterial lipids by de novo synthesis of propionic acid produced in ruminal fermentation (FERNANDES et al., 2009) (Table 4). Our results are similar to those reported by Jian-bin et al. (2015) for intramuscular lipids of Oula lambs, but present greater values than that were found by D'Alessandro et al. (2015) in Leccese and Comisana lambs. Although there was an increase in $\mathrm{C} 17: 0$ content with increased body weight of the animals, this characteristic is not expected to be detrimental as $\mathrm{C17:0}$ has been reported as being beneficial to human health, particularly in helping to prevent diabetes and coronary diseases (JENKINS et al., 2015).

Stearic acid (C18:0) was also significantly affected $(\mathrm{P}<0.05)$ by body weight. A greater body weight corresponded to a lower concentration of stearic acid in the $35 \mathrm{~kg}$ lambs (Table 4), which may have been due to the activity of $\Delta 9$-desaturase as this enzyme uses FAs as a substrate to convert stearic acid (C18:0) to oleic acid (C18:1n-9). Our findings are in agreement with Budimir et al. (2018) working with Bergamasca light lambs slaughtered at 40 and 60 days, but contrary to the reported by Jianbin et al. (2015), where the concentration of stearic acid in Oula lambs tended to increase, although not significantly. Although stearic acid is saturated, it is considered to be a neutral FA that does not interfere with serum cholesterol levels in humans; additionally, it has a positive effect in preventing cardiovascular diseases (MARTEMUCCI; D'ALESSANDRO, 2013) and, as such, it does not affect the lipid profile.

Among the total FAs identified, monounsaturated oleic acid (C18:1 n-9), known for its cholesterollowering properties, was significantly affected $(\mathrm{P}<0.05)$, presenting higher values with increased weights at slaughter (Table 4). In this study, the highest amount of C18:1 was found in intramuscular fat, in agreement with the results of Jian-bin et al. (2015) who also reported high values for lambs at 35, 40 and $45 \mathrm{~kg}$ slaughter weights. According to Sañudo et al. (2000), this FA is found at high concentrations in ruminant intramuscular fat and is synthesized from stearic acid by the $\Delta 9$ desaturase enzyme (WOOD et al., 2008). A high concentration of oleic acid in meat is a highly desirable characteristic; as we observed a decrease in oleic acid content with increasing body weight, this suggests that animals with lower body weight present more desirable meat.

Linoleic acid (C18:2n-6) was found in low amounts and tended to decrease with increasing body weight (Table 4). This reduction may be due to the biohydrogenation process in the rumen, where PUFAs are transformed into SFAs as a way of preventing toxicity of rumen bacteria; the SFAs are subsequently absorbed and incorporated into muscle tissue. The decreasing trend observed is an undesirable trait as linoleic acid is beneficial to health, having a role in controlling serum cholesterol and brain functions (SENEGALHE et al., 2014). In agreement with our study, findings reported by Budimir et al. (2018) in Bergamasca lambs and Polidori et al. (2017) in Fabrianese lambs also showed reduced linoleic acid content with increasing age at slaughter.

The total SFA, unsaturated FA (UFA), MUFA, and PUFA levels were influenced $(\mathrm{P}<0.05)$ by body weight (Table 5). The average highest content found in this study were for UFAs $\left(533.8 \mathrm{~g} \mathrm{~kg}^{-1}\right)$ and MUFAs (470.9 $\left.\mathrm{g} \mathrm{kg}^{-1}\right)$, but low content of SFAs (460.6 $\mathrm{g}$ $\left.\mathrm{kg}^{-1}\right)$ and PUFAs $\left(62.8 \mathrm{~g} \mathrm{~kg}^{-1}\right)$ were also observed. This may have been due to the large participation of oleic acid originating from the conversion of stearic to oleic acid, which would be expected to increase the UFA and MUFA ratios, and a low contribution of linoleic acid (PUFA) and SFAs to the FA profile. However, in relation to body weight, in this report we observed that the concentration of SFAs increased, while the concentrations of UFAs, 
MUFAs, and PUFAs decreased, with increasing weight at slaughter.

Saturated fatty acid content was significantly $(\mathrm{P}<0.05)$ higher $\left(476.0 \mathrm{~g} \mathrm{~kg}^{-1}\right)$ in lambs slaughtered at $35 \mathrm{~kg}$ of body weight compared to the youngest (Table 5). This observation can be attributed to the major hydrogenation performed by microorganisms in the completely functional rumen of older animals, which are adapted and ready to a dry diet. High rates of SFAs are not a desirable trait as they have been associated with the risk of developing coronary heart disease, due to increased plasma cholesterol and plasma LDL (Low Density Lipoprotein) levels in consumers (GAZZOLA; DEPIN, 2015). Matsushita et al. (2010), studying Bergamacia and Corriedale lambs slaughtered at different weights in a feedlot system, as well as Della Malva et al. (2016), studying Altamurana lambs slaughtered at 40 and 75 days of age, also reported higher levels of SFAs in heavier animals $\left(513.0 \mathrm{~g} \mathrm{~kg}^{-1}\right.$ and 496.4 $\mathrm{g} \mathrm{kg}^{-1}$, respectively). Taken together, these results indicated that meat of lambs of lower body weights were healthier for human consumption.

Table 5. Sums and ratios of fatty acid composition of Longissimus lumborum muscle ( $\mathrm{g} \mathrm{kg}^{-1}$ fat) from Pantaneiro lambs at different body weights.

\begin{tabular}{|c|c|c|c|c|c|c|c|}
\hline \multirow{2}{*}{ Fatty acid } & \multicolumn{5}{|c|}{ Body weights } & \multirow{2}{*}{ CV $(\%)$} & \multirow{2}{*}{$P$} \\
\hline & 15 & 20 & 25 & 30 & 35 & & \\
\hline $\mathrm{SFA}^{1}$ & $445.2 \pm 0.7$ & $449.6 \pm 0.7$ & $460.2 \pm 1.2$ & $472.0 \pm 1.4$ & $476.0 \pm 1.1$ & 2.65 & $<0.0001$ \\
\hline $\mathrm{UFA}^{2}$ & $548.4 \pm 0.4$ & $543.2 \pm 0.9$ & $531.6 \pm 1.0$ & $526.8 \pm 0.9$ & $518.9 \pm 0.5$ & 2.04 & $<0.0001$ \\
\hline MUFA $^{3}$ & $482.9 \pm 0.4$ & $477.7 \pm 1.1$ & $468.6 \pm 0.2$ & $466.2 \pm 1.1$ & $459.2 \pm 0.4$ & 1.81 & $<0.0001$ \\
\hline PUFA $^{4}$ & $65.4 \pm 0.5$ & $65.5 \pm 0.4$ & $63.0 \pm 0.9$ & $60.6 \pm 0.8$ & $59.7 \pm 0.3$ & 3.99 & $<0.0001$ \\
\hline PUFA/SFA ${ }^{5}$ & $1.5 \pm 0.0$ & $1.5 \pm 0.0$ & $1.4 \pm 0.0$ & $1.3 \pm 0.0$ & $1.3 \pm 0.0$ & 6.56 & $<0.0001$ \\
\hline$n-3$ & $17.7 \pm 0.3$ & $17.6 \pm 0.3$ & $16.4 \pm 0.3$ & $16.6 \pm 0.8$ & $17.6 \pm 0.3$ & 4.13 & 0.131 \\
\hline$n-6^{6}$ & $40.1 \pm 0.4$ & $40.5 \pm 0.6$ & $38.2 \pm 0.7$ & $36.6 \pm 0.6$ & $34.5 \pm 0.2$ & 6.11 & $<0.0001$ \\
\hline$n-6 / n-3^{7}$ & $22.7 \pm 0.5$ & $23.1 \pm 0.7$ & $23.4 \pm 0.6$ & $22.1 \pm 1.3$ & $19.6 \pm 0.4$ & 6.97 & $<0.0001$ \\
\hline$h^{8}$ & $508.3 \pm 0.5$ & $502.7 \pm 0.9$ & $492.5 \pm 0.7$ & $488.1 \pm 0.7$ & $478.7 \pm 0.4$ & 2.15 & $<0.0001$ \\
\hline $\mathrm{H}^{9}$ & $253.1 \pm 0.4$ & $265.6 \pm 1.0$ & $278.2 \pm 0.8$ & $288.2 \pm 0.5$ & $299.4 \pm 1.0$ & 5.96 & $<0.0001$ \\
\hline $\mathrm{h} / \mathrm{H}^{10}$ & $20.1 \pm 0.0$ & $18.9 \pm 0.1$ & $17.7 \pm 0.1$ & $16.9 \pm 0.0$ & $16.0 \pm 0.1$ & 8.15 & $<0.0001$ \\
\hline $\mathrm{AI}^{11}$ & $6.0 \pm 0.0$ & $6.4 \pm 0.0$ & $6.9 \pm 0.0$ & $7.2 \pm 0.0$ & $7.6 \pm 0.0$ & 8.37 & $<0.0001$ \\
\hline $\mathrm{TI}^{12}$ & $13.3 \pm 0.0$ & $13.5 \pm 0.1$ & $14.3 \pm 0.0$ & $14.7 \pm 0.1$ & $14.8 \pm 0.1$ & 4.38 & $<0.0001$ \\
\hline$\Delta^{9}-\operatorname{des} 16^{13}$ & $67.3 \pm 0.5$ & $65.2 \pm 1.1$ & $60.4 \pm 0.7$ & $59.8 \pm 1.2$ & $58.3 \pm 0.4$ & 5.74 & $<0.0001$ \\
\hline$\Delta^{9}-\operatorname{des} 18^{14}$ & $730.9 \pm 0.7$ & $738.4 \pm 0.6$ & $737.1 \pm 0.4$ & $736.2 \pm 1.5$ & $743.1 \pm 0.5$ & 0.55 & $<0.0001$ \\
\hline
\end{tabular}

$\mathrm{SFA}=$ saturated fatty acids; UFA $=$ unsaturated fatty acids; MUFA $=$ monounsaturated fatty acids; PUFA $=$ polyunsaturated fatty acids; $\mathrm{AI}=$ atherogenicity index; $\mathrm{TI}=$ thrombogenicity index; $\mathrm{h}=$ hypocholesterolemic fatty acids; $\mathrm{H}=$ hypercholesterolemic fatty acids; $\Delta^{9}$-des $16=$ desaturase 16 enzyme activity; $\Delta^{9}$-des $18=$ desaturase 18 enzyme activity.

${ }^{1} \mathrm{y}=40.6253+0.2599 \mathrm{x}-0.001797 \mathrm{x}^{2}\left(\mathrm{R}^{2}=0.94\right) ;{ }^{2} \mathrm{y}=58.4003-0.2444 \mathrm{x}+0.001811 \mathrm{x}^{2}\left(\mathrm{R}^{2}=0.97\right) ;{ }^{3} \mathrm{y}=51.2488-$ $0.2105 \mathrm{x}+0.001792 \mathrm{x}^{2}\left(\mathrm{R}^{2}=0.96\right) ;{ }^{4} \mathrm{y}=7.1515-0.03397 \mathrm{x}+0.00001872 \mathrm{x}^{2}\left(\mathrm{R}^{2}=0.89\right) ;{ }^{5} \mathrm{y}=0.1732-0.001642 \mathrm{x}+$ $0.000008303 \mathrm{x}^{2}\left(\mathrm{R}^{2}=0.92\right) ;{ }^{6} \mathrm{y}=4.1127+0.008641 \mathrm{x}-0.07454 \mathrm{x}^{2}\left(\mathrm{R}^{2}=0.91\right) ;{ }^{7} \mathrm{y}=1.4380+0.07991 \mathrm{x}-0.001792 \mathrm{x}^{2}$ $\left(\mathrm{R}^{2}=0.73\right) ;{ }^{8} \mathrm{y}=53.8001-0.1959 \mathrm{x}+0.0009417 \mathrm{x}^{2}\left(\mathrm{R}^{2}=0.97\right) ;{ }^{9} \mathrm{y}=19.7628+0.3951 \mathrm{x}-0.003195 \mathrm{x}^{2}\left(\mathrm{R}^{2}=0.98\right) ;{ }^{10} \mathrm{y}$ $=2.5621-0.04055 \mathrm{x}+0.0003894 \mathrm{x}^{2}\left(\mathrm{R}^{2}=0.98\right) ;{ }^{11} \mathrm{y}=0.56+0.039 \mathrm{x}\left(\mathrm{R}^{2}=0.99\right) ;{ }^{12} \mathrm{y}=0.12+0.041 \mathrm{x}\left(\mathrm{R}^{2}=0.93\right) ;{ }^{13} \mathrm{y}$ $=8.5001-0.1350 \mathrm{x}+0.001688 \mathrm{x}^{2}\left(\mathrm{R}^{2}=0.90\right) ;{ }^{14} \mathrm{y}=72.5375+0.04696 \mathrm{x}-0.00005204 \mathrm{x}^{2}\left(\mathrm{R}^{2}=0.61\right)$. 
The PUFA content was relatively low in relation to other FAs and tended to decrease with increasing body weight of the animals (from 65.4 to $59.7 \mathrm{~g}$ $\mathrm{kg}^{-1}$ ) (Table 5). This lower PUFA content in the meat is also likely due to the biohydrogenation process, where the PUFAs are transformed into SFAs by rumen bacteria. According to Pelegrini et al. (2007), the PUFAs located in cell membranes are precursors of different eicosanoids, which act as cellular messengers and metabolic regulators, and whose specific functions are of particular interest in the study of cardiovascular diseases. Unlike some SFAs, MUFAs, and PUFAs are considered effective in reducing blood cholesterol levels in humans and, additionally, MUFAs can inhibit arterial platelet aggregation (PERINI et al., 2010). In our study, however, the concentrations of these fatty acids decreased (from 482.9 to $459.2 \mathrm{~g} \mathrm{~kg}^{-1}$ ) with increasing lamb body weight. Matsushita et al. (2010), working with ram lambs with weights between 28 to $40 \mathrm{~kg}$ in a feedlot system, also noted a reduction of MUFA (from 433.4 to $389.4 \mathrm{~g} \mathrm{~kg}^{-1}$ ) and PUFA (from 135.4 to $97.6 \mathrm{~g} \mathrm{~kg}^{-1}$ ) concentrations in heavier lambs.

The PUFA/SFA ratio was also affected $(\mathrm{P}<0.05)$ by body weight, showing a decreasing trend with increasing body weight of the lambs (Table 5). The mean value observed in this study was $1.4 \mathrm{~g}$ $\mathrm{kg}^{-1}$, with improved content seen in animals at 15 and $25 \mathrm{~kg}\left(1.5 \mathrm{~g} \mathrm{~kg}^{-1}\right)$, but still considerably less than the recommended value for human health ( $>$ $4.0 \mathrm{~g} \mathrm{~kg}^{-1}$ ) (WOOD et al., 2004). Our results are consistent with those of Jian-bin et al. (2015), who found values similar to ours on average $\left(1.7 \mathrm{~g} \mathrm{~kg}^{-}\right.$ ${ }^{1}$ ), but considerably less than the recommended values; nevertheless, both Matsushita et al. (2010) and Senegalhe et al. (2014) reported values very close to recommended levels (2.3 and $3.8 \mathrm{~g} \mathrm{~kg}^{-1}$, respectively) displaying meat with best quality. The low values seen in our study may be attributed to the high degree of biohydrogenation of dietary PUFAs by ruminal microorganisms, indicating that sheep meat may normally have higher levels of SFAs, and a lower ratio of PUFAs/SFAs. A low PUFA/SFA ratio is considered an unfavorable characteristic as these FAs have been shown to have a role in increasing cholesterolemia (SANTOS-SILVA et al., 2002). Thus, in our study, the meat of lighter lambs presented better nutritional quality.

No effect $(\mathrm{P}>0.05)$ of body weight was found on $n-3$ FAs, whereas the content of n- 6 FAs were stable at $38.0 \mathrm{~g} \mathrm{~kg}^{-1}$, on average (Table 5). The $\mathrm{n}-6 / \mathrm{n}-3$ ratio was significantly affected $(\mathrm{P}<0.05)$ by body weight (Table 5 ), showing a lower value (19.6 $\mathrm{g} \mathrm{kg}^{-1}$ ) in older animals compared to younger ones $\left(22.7 \mathrm{~g} \mathrm{~kg}^{-1}\right)$. Other researchers have also reported lower levels of this parameter in older animals; for example, Matsushita et al. (2010) observed a value of $13.2 \mathrm{~g} \mathrm{~kg}^{-1}$ in lambs slaughtered at 28 to $40 \mathrm{~kg}$, and Polidori et al. (2017) found a value of $34.3 \mathrm{~g} \mathrm{~kg}^{-1}$ in Fabrianese lambs slaughtered at 2 and 5 months of age. All the values were within the nutritional recommendations for human $\operatorname{diet}\left(<40.0 \mathrm{~g} \mathrm{~kg}^{-1}\right)$, as indicated by Lorenzo et al. (2010). However, Jianbin et al. (2015), studying Oula lambs slaughtered at 25 to $45 \mathrm{~kg}$, observed particularly high values in animals of $40 \mathrm{~kg}\left(114.7 \mathrm{~g} \mathrm{~kg}^{-1}\right)$, which the authors attributed this result to the type of feed of these animals, consisting exclusively of native pasture.

The total value for hypocholesterolemic FAs (h) was $494.1 \mathrm{~g} \mathrm{~kg}^{-1}$ on average, and this content decreased with increasing body weight (Table 5). In contrast, the content of hypercholesterolemic FAs (H) was $276.9 \mathrm{~g} \mathrm{~kg}^{-1}$ on average and increased with increasing body weight. The hypocholesterolemic / hypercholesterolemic ratio $(\mathrm{h} / \mathrm{H})$ in the present study decreased with increasing body weight, showing an average of $17.9 \mathrm{~g} \mathrm{~kg}^{-1}$. The $\mathrm{h} / \mathrm{H}$ ratio is based on the functional effects of FAs on cholesterol metabolism (ARRUDA et al., 2012), and, according to Sousa Bentes et al. (2009), the higher the $\mathrm{h} / \mathrm{H}$ ratio, the more nutritionally adequate the oil or fat in the food is. However, in our study we observed the opposite; lambs with greater body weight exhibited increased levels of hypercholesterolemic FAs and decreased levels of hypocholesterolemic FAs and 
$\mathrm{h} / \mathrm{H}$ ratios, making the meat of heavier Pantaneiro lambs less appropriate for human consumption. Therefore, lambs with lower body weights have more nutritional quality than heavier ones.

The atherogenicity (AI) and thrombogenicity (TI) indexes had mean values ranging from $6.8 \mathrm{~g} \mathrm{~kg}^{-1}$ to $14.1 \mathrm{~g} \mathrm{~kg}^{-1}$, respectively, and tended to increase in heavier animals (Table 5). These indexes are related to pro- and antiatherogenic acids and indicate the potential stimulus for platelet aggregation, i.e., the lower the AI and TI values, the greater the content of antiatherogenic FAs in the food and, consequently, the greater the potential to prevent the occurrence of coronary disease (ARRUDA et al., 2012). In our case, the meat of the lighter animals was shown to be better than the heavier ones. In accordance with our results, Della Malva et al. (2016) and D'Alessandro et al. (2015) also found higher levels of AI and TI in older lambs.

The index that assesses the activity of enzyme $\Delta$-desaturase 16 was low $\left(62.2 \mathrm{~g} \mathrm{~kg}^{-1}\right)$ and decreased with increasing body weight (Table 5). In contrast, enzyme $\Delta^{9}$-desaturase 18 was found at high concentrations $\left(737.1 \mathrm{~g} \mathrm{~kg}^{-1}\right)$. The enzymes $\Delta^{9}$-desaturase 16 and 18 are responsible for the conversion of the SFAs with 16 and 18 carbon atoms, respectively, into their corresponding MUFAs containing a double bond on carbon 9, as described by Malau-Aduli et al. (1997). The index expresses the amount of product (MUFAs) as a percentage of substrate available for conversion. Enzyme $\Delta^{9}$-desaturase 16 was found at low levels and showed a downward trend as the animals' body weight increased. This result suggests that a small proportion of the palmitic acid (substrate) is being converted into its corresponding MUFA, palmitoleic acid (product), by the activity of this enzyme. In this case, it is likely that palmitic acid (C16:0), the final product of the FA synthetase enzyme, is being elongated into stearic acid (C18:0) by the introduction of a double bond between carbon 9 and 10 , catalyzed by the enzyme elongase; in turn, stearic acid is being desaturated by $\Delta^{9}$-desaturase
18 and converted into oleic acid, which is found at high levels (MOREIRA et al., 2002). The index that assesses the activity of enzyme $\Delta^{9}$-desaturase 18 is calculated by a mathematical model that takes into account the content of oleic acid in tissues (LOPES et al., 2012b). The high quantities of oleic acid present in the muscle of those animals suggests intense activity of this enzyme.

\section{Conclusions}

Different body weights influenced significantly the nutritional, physical, and chemical properties of Pantaneiro lamb meat. The qualitative characteristics of the meat were markedly better in the animals with the highest body weight $(35 \mathrm{~kg}$ ), but the chemical characteristics and the FA profile were better in the animals with the lowest body weight $(15 \mathrm{~kg})$, indicating that they are more favorable to human health. Therefore, under the conditions of the experiment, it was concluded that the meat of lambs slaughtered at lower body weights presented better nutritional quality, making it more suitable for human consumption.

\section{Acknowledgements}

The authors thank the National Council for Scientific and Technological Development (CNPq) and the Foundation of Support to the Development of Teaching, Science and Technology of the state of Mato Grosso do Sul (FUNDECT) for the financial support, and the Federal University of Grande Dourados for the technical and institutional support.

\section{References}

ABDULLAH, A. Y.; QUDSIEH, R. I. Effect of slaughter weight and aging time on the quality of meat from Awassi ram lambs. Meat Science, Cowra, v. 82, n. 3, p. 309-316, July 2009.

ARRUDA, P. C. L.; PEREIRA, E. S.; PIMENTEL, I. Y.; BOMFIM, M. A. D.; MIZUBUTI, I. Y.; RIBEIRO, E. L. A.; FONTENELE, R. M.; REGADAS FILHO, J. 
G. L. Perfil de ácidos graxos no Longissimus lumborum de cordeiros Santa Inês alimentados com diferentes níveis energéticos. Semina: Ciências Agrárias, Londrina, v. 33, n. 3, p. 1229-1240, maio/jun. 2012.

ASSOCIATION OF OFFICIAL ANALYTICAL CHEMISTIS - AOAC. Official methods of analysis. $18^{\text {th }}$ Ed. Washington: AOAC International, 2010.

BLIGH, E. G.; DYER, W. J. A rapid method for total lipid extraction and purification. Canadian Journal of Biochemistry and Physiology, Ottawa, v. 37, n. 8, p. 911917, 1959.

BOLEMAN, S. J.; BOLEMAN, S. L.; MILLER, R. K.; TAYLOR, J. F.; CROSS, H. R.; WHEELER, T. L.; KOOHMARAIE, M.; SHACKELFORD, S. D.; MILLER, F. F.; WEST, R. L.; JOHSSON, D. D.; SAVELL, J. W. Consumer evaluation of beef of known categories of tenderness. Journal of Animal Science, Champaign, v. 75, n. 6, p. 1521-1524, june 1997.

BUDIMIR, K.; TROMBETTA, M. F.; FRANCIONI, M.; TODERI, M.; D'OTTAVIO, P. Slaughter performance and carcass and meat quality of Bergamasca light lambs according to slaughter age. Small Ruminant Research, Bet Dagan, v. 164, n. 1, p. 1-7, july 2018.

CALDER, P. C. Functional roles of fatty acids and their effects on human health. Journal of Parenteral and Enteral Nutrition, Chicago, v. 39, p. 18-32, Sept. 2015. Supplement 1.

CAÑEQUE, V.; SAÑUDO, C. Metodología para el estúdio de la calidad de la canal y de la carne en rumiantes. Madrid: Instituto Nacional de Investigación y Tecnología y Alimentaria, 2005. 255 p.

COSTA, R. S.; HENRIQUES, L. S. V.; TAVARES, E. M.; ALVES, E. N.; HENRY, F. C.; QUIRINO, C. R. Qualidade da carne de cordeiros Santa Inês e F1 Santa Inês X Dorper. Revista Brasileira de Medicina Veterinária, Rio de Janeiro, v. 36, n. 3, p. 337-343, jul./ set. 2014.

D'ALESSANDRO, A. G.; PALAZZO, M.; PETROTOS, K.; GOULAS, P.; MARTEMUCCI, G. Fatty acid composition of light lamb meat from Leccese and Comisana dairy breeds as affected by slaughter age. Small Ruminant Research, Bet Dagan, v. 127, n. 1, p. 3643 , june 2015.

DELLA MALVA, A.; ALBENZIO, M.; ANNICCHIARICO, G.; CAROPRESE, M.; MUSCIO, A.; SANTILLO, A.; MARINO, R. Relationship between slaughtering age, nutritional and organolepticproperties of Altamurana lamb meat. Small Ruminant Research, Bet Dagan, v. 135, n. 1, p. 39-45, feb. 2016.
FERNANDES, A. R. M.; SAMPAIO, A. A. M.; HENRIQUE, W.; TULLIO, R. R.; OLIVEIRA, E. A. de; SILVA, T. M. da. Composição química e perfil de ácidos graxos da carne de bovinos de diferentes condições sexuais recebendo silagem de milho e concentrado ou cana de açúcar e concentrado contendo grãos de girassol. Revista Brasileira de Zootecnia, Viçosa, v. 38, n. 4, p. 705-712, apr. 2009.

FERRÃO, S. P. B.; BRESSAN, M. C.; OLIVEIRA, R. P.; PEREZ, J. R. O.; RODRIGUES, E. C.; NOGUEIRA, D. A. Características sensoriais da carne de cordeiros da raça Santa Inês submetidos a diferentes dietas. Ciência e Agrotecnologia, Lavras, v. 33, n. 1, p. 185-190, jan./ fev. 2009.

GAZZOLA, J.; DEPIN, M. H. Associação entre consumo de gordura trans e o desenvolvimento de doenças cardiovasculares. Revista Eletrônica de Extensão, Florianópolis, v. 12, n. 20, p. 90-102, 2015.

JACOB, R. H.; PETHICK, D. W. Animal factors affecting the meat quality of Australian lamb meat. Meat Science, Cowra, v. 96, n. 2, Part B, p. 1120-1123, feb. 2014.

JENKINS, B.; WEST, J. A.; KOULMAN, A. A review of odd-chain fatty acid metabolism and the role of pentadecanoic acid (C15:0) and heptadecanoic acid (C17:0) in health and disease. Molecules, Basel, v. 20, n. 2, p. 2425-2444, jan. 2015.

JIAN-BIN, L.; JIAN, G.; FAN, W.; YAO-JING, Y.; WANLONG, Z.; RUI-LIN, F.; TING-TING, G.; BO-HUI, Y.; XIAO-PING, S. Carcass and meat quality characteristics of Oula lambs in China. Small Ruminant Research, Bet Dagan, v. 123, n. 2-3, p. 251-259, feb. 2015.

LOPES, J. E. L.; SALES, R. O.; AZEVEDO, A. R.; OLIVEIRA, A. L. T. Composição centesimal, perfil de ácidos graxos e colesterol da carne de cordeiros submetidos aos sistemas de produção com dieta experimental e convencional. Revista Brasileira de Higiene e Sanidade Animal, Fortaleza, v. 6, n. 2, p. 3150, 2012a.

LOPES, L. S.; LADEIRA, M. M.; MACHADO NETO, O. R.; RAMOS, E. M.; PAULINO, P. V. R.; CHIZZOTI, M. L.; GUERREIRO, M. C. Composição química e de ácidos graxos do músculo longissimus lumborum e da gordura subcutânea de tourinhos Red Norte e Nelore. Revista Brasileira de Zootecnia, Viçosa, v. 41, n. 4, p. 978-985, abr. 2012b.

LORENZO, J. M.; FUCIÑOS, C.; PURRIÑOS, L.; FRANCO, D. Intramuscular fatty acid of Galician Mountains foals breed. Effect of sex, slaughtered age and livestock production system. Meat Science, Cowra, v. 86, n. 3 , p. $825-831$, nov. 2010 . 
MADRUGA, M. S.; ARAÚJO, W. O.; SOUSA, W. H.; CÉZAR, M. F.; GALVÃO, M. S.; CUNHA, M. G. G. Effect of genotype and sex on chemical composition and fatty acid profile of sheep meat. Revista Brasileira de Zootecnia, Viçosa, v. 35, n. 4. p. 1838-1844, july/aug. 2006. Supplement.

MALAU-ADULI, A. E. O.; SIEBERT, B. D.; BOTTEMA, C.D.K.; PITCHFORD, W. S.Acomparison of the fatty acid composition of tryacilglycerols in adipose tissue from Limousin and Jersey cattle. Australian Journal of Agriculture Research, Clayton South, v. 48, n. 5, p. 715-722, 1997.

MARTEMUCCI, G.; D’ALESSANDRO, A. G. Progress in nutritional and health profile of milk and dairy products: a novel drug target. Endocrine, Metabolic and Immune Disorders - Drug Targets, Bari, v. 13, n. 3, p. 209-233, sept. 2013.

MATSUSHITA, M.; MARTINS JUNIOR, A. C.; GOMES, S. T. M.; MACEDO, F. A. F.; VISENTAINER, J. V.; SOUZA, N. E. Influence of slaughter weight on the proximate composition and fatty acid profile of feedlotfattened lamb meat. Acta Scientiarum Technology. Maringá, v. 32, n. 3, p. 315-318, 2010.

MOLONEY, A. P.; KENNEDY, C.; NOCI, F.; MONAHAN, F. J.; KERRY, J. P. Lipid and colour stability of M. longissimus muscle from lambs fed camelina or linseed as oil or seeds. Meat Science, Cowra, v. 92, n. 1, p. 1-7, sept. 2012.

MONTE,A.L. S.; GONSALVES, H.R. O.; VILARROEL, A. B. S.; DAMACENO, M. N.; CAVALCANTE, A. B. D. Qualidade da carne de caprinos e ovinos: uma revisão. Agropecuária Científica no Semi-Árido, Patos, v. 8, n. 3, p. 11-17, jul./set. 2012.

MOREIRA, N. X.; CURI, R.; MANCINI FILHO, J. Fatty acids: a review. Nutrire: Revista da Sociedade Brasileira de Alimentação e Nutrição, São Paulo, v. 24, n. 1, p. 105-123, dec. 2002.

OLIVEIRA, D. P.; OLIVEIRA, C. A. L.; MARTINS, E. N.; VARGAS JUNIOR, F. M.; SENO, L. O.; SANTOS PINTO, G.; SASA, A.; BARBOSA-FERREIRA, M. Parâmetros genéticos para características de desempenho em ovinos naturalizados Sul-Mato-Grossenses. Semina: Ciências Agrárias, Londrina, v. 35, n. 2, p. 963-972, mar./abr. 2014.

OSÓRIO, M. T. M.; OSÓRIO, J. C. S.; SILVA SOBRINHO, A. G. Avaliação instrumental da carne ovina. In: SILVA SOBRINHO, A. G.; SAÑUDO, C.; OSÓRIO, J. C. S.; ARRIBAS, M. M. C.; OSÓRIO, M. T. M. (Org.). Produção de carne ovina. Jaboticabal: Funep, 2008. p. 129-176.
PELEGRINI, L. F.V.; PIRES, C. C.; KOZLOSKI, G. V.; TERRA, N. N.; BAGGIO, S. R.; BASTIANELLO, P. C.; CAMPAGNOL, P. C. B.; GALVANI, D. B.; CHEQUIM, R. M. Perfil de ácidos graxos da carne de ovelhas de descarte de dois grupos genéticos submetidas a dois sistemas de manejo. Ciência Rural, Santa Maria, v. 37, n. 6, p. 1786-1790, nov./dez. 2007.

PERINI, J. A. L.; STEVANATO, F. B.; SARGI, S. C.; VISENTAINER, J. E. L.; DALALIO, M. M. O.; MATSHUSHITA, M.; SOUZA, N. E.; VISENTAINER, J. V. Ácidos graxos poli-insaturados n-3 e n-6: metabolismo em mamíferos e resposta imune. Revista de Nutrição, Campinas, v. 23, n. 6, p. 1075-1086, nov./dez. 2010.

PFLANZER, S. B.; FELÍCIO, P. E. de. Moisture and fat content, marbling level and color of boneless rib cut from Nellore steers varying in maturity and fatness. Meat Science, Cowra, v. 87, n. 1, p. 7-11, jan. 2011.

POLIDORI, P.; PUCCIARELLI, S.; CAMMERTONI, N.; POLZONETTI, V.; VINCENZETTI, S. The effects of slaughter age on carcass and meat quality of Fabrianese lambs. Small Ruminant Research, Bet Dagan, v. 155, n. 1, p. 12-15, oct. 2017.

SANTOS, V. A. C.; CABO, A.; RAPOSO, P.; SILVA, J. A.; AZEVEDO, J. M. T.; SILVA, S. R. The effect of carcass weight and sex on carcass composition and meat quality of Cordeiro Mirandês - Protected designation of origin lambs. Small Ruminant Research, Bet Dagan, v. 130, n. 1, p. 136-140, sept. 2015.

SANTOS-SILVA, J.; BESSA, R. J. B.; SANTOSSILVA, F. The effect of genotype, feeding system and slaughter weight on the quality of light lamb. II Fatty acid composition of meat. Livestock Production Science, Foulum, v. 77, n. 2-3, p. 187-194, nov. 2002.

SAÑUDO, C.; ENSER, M. E.; CAMPO, M. M.; NUTE, G. R.; MARIA, G.; SIERRA, I.; WOOD, J. D. Fatty acid composition and sensory characteristics of lamb carcasses from Britain and Spain. Meat Science, Cowra, v. 54, n. 4, p. 339-346, apr. 2000.

SENEGALHE, F. B. D.; BURIN, P. C.; FUZIKAWA, I. H. S.; PENHA, D. S.; LEONARDO, A. P. Ácidos graxos na carne e gordura de ovinos. Enciclopédia Biosfera, Goiânia, v. 10, n. 18, p. 80-101, 2014.

SOUSA BENTES, A.; SOUZA, H. A. L.; SIMÕES, M. G.; MENDONÇA, X. M. F. D. Caracterização física e química e perfil lipídico de três espécies de peixes amazônicos. Revista Brasileira de Tecnologia Agroindustrial, Ponta Grossa, v. 3, n. 2, p. 97-108, 2009.

SOUZA, X. R.; BRESSAN, M. C.; PÉREZ, J. R. O.; FARIA, P. B.; VIEIRA, J. O.; KABEYA, D. M. 
Efeitos de grupo genético, sexo e peso ao abate sobre as propriedades físico-químicas da carne de cordeiros em crescimento. Ciência e Tecnologia de Alimentos, São Paulo, v. 24, n. 4, p. 543-549, dez. 2004.

UlBriCHT, T. L.; SOUTHGATE, D. A. Coronary heart disease: seven dietary factors. The Lancet, London, v. 338, n. 8773, p. 985-992, 1991.

VARGAS JUNIOR, F. M.; LONGO, M. L.; SENO, L. O.; SANTOS PINTO, G.; BARBOSA-FERREIRA, M.; OLIVEIRA, D. P. Potencial produtivo de um grupamento genético de ovinos nativos Sul matogrossenses. Pubvet, Londrina, v. 5, n. 30, ed. 177, Art. 1197, 2011.

WOOD, J. D.; ENSER, M.; FISHER, A. V.; NUTE, G. R.; SHEARD, P. R.; RICHARDSON, R. I.; HUGHES, S. I.; WHITTINGTON, F. M. Fat deposition, fatty acid composition and meat quality: a review. Meat Science, Cowra, v. 78, n. 4, p. 343-358, apr. 2008.

WOOD, J. D.; RICHARDSON, R. I.; NUTE, G. R.; FISHER, A. V.; CAMPO, M. M.; KASAPIDOU, E.; SHEARD, P. R.; ENSER, M. Effects of fatty acids on meat quality: a review. Meat Science, Cowra, v. 66, n. 1, p. 21-32, jan. 2004 .

XLSTAT. Versão 2014.4.01. Pacote estatístico. Paris: Addinsoft, 2014.

ZEOLA, N. M. B. L.; SOUZA, P. A.; SOUZA, H. B. A.; SILVA SOBRINHO, A. G. Parâmetros qualitativos da carne ovina: um enfoque à maturação e marinação. Revista Portuguesa de Ciências Veterinárias, Lisboa, v. 102, n. 563-564, p. 215-224, 2007. 
